Article

\title{
Multi-Criteria Analysis of Design Solutions in Architecture and Engineering: Review of Applications and a Case Study
}

\author{
Karolina Ogrodnik (1) \\ Faculty of Civil Engineering and Environmental Sciences, Bialystok University of Technology, \\ 15-351 Bialystok, Poland; k.ogrodnik@pb.edu.pl
}

Received: 24 November 2019; Accepted: 13 December 2019; Published: 17 December 2019

\begin{abstract}
The primary goal of this paper is to present the application potential of MCDM/MCDA (multi-criteria decision-making/multi-criteria decision analysis) methods in the field of architecture and urban planning and in energy efficient construction, especially in the context of sustainable development paradigm. The first part of this paper is devoted to literature studies pertaining to multi-criteria decision-making support in the selected fields. On the basis of the delivered review, it was demonstrated that the most popular methods belonging to the MCDM/MCDA group that have been used so far for the purpose of resolving selected decision-making challenges, is the AHP (analytic hierarchy process) method with modifications, TOPSIS (technique for order of preference by similarity to ideal solution) method, as well the up-and-coming COPRAS (complex proportional assessment) method. In addition, by reviewing the literature, it was found that MCDM/MCDA methods constitute an effective support tool at the stage of evaluating and selecting project solutions, and are especially helpful in framing various social, economic, environmental criteria that are permanently linked to the rule of sustainable development. The empirical section of this paper, through a case study, presents a comparative analysis of the classical AHP method with its extension onto fuzzy sets. The case study pertained to the criteria for the location of single-family residential buildings with solar installations.
\end{abstract}

Keywords: multi-criteria decision-making; multi-criteria decision analysis; fuzzy AHP; sustainable development; design solutions

\section{Introduction}

The concept of sustainable development serves as the answer to the current civilization shifts and the relentless growth of the population, economy, and technology [1]. Many definitions of sustainable development exist, but the most popular one can be found in Brundtland's Report, "Our Common Future" [2]. The concept of sustainable development constitutes, without a doubt, an important research subject from a theoretical standpoint and-from a practical point of view-it determines the direction of development in multiple fields. The concept of sustainable development is increasingly frequently seen in construction engineering, which includes all stages of a building's lifecycle, starting from the design phase, through the construction work, its planning and management, all the way to its usage [3]. In the light of the growing climate changes and legal requirement, energy-efficient construction plays a key role.

Contemporary architectural design and urban planning are also based on the sustainable development paradigm. Establishing sustainable city structures is one of the challenges of modern urban planning [4]. In city policy-making, the assumptions of sustainable models and developmental concepts such as compact city, smart city, or green city are more frequently taken into account [5]. 
Architecture, urban planning, and construction, including energy-efficient construction are all connected fields that shape our common space and meaningfully impact the environment and climate. Additionally, everyday decision problems in the field of architecture and urban planning and construction, such a selecting an architectural design [6], a revitalization scenario [7], or a construction solution [8], require a multi-criteria approach, the inclusion of various, often contradictory decision factors as well as taking into account the preferences of the stakeholders. Here, methods from MCDM/MCDA (multi-criteria decision-making/multi-criteria decision analysis) groups can serve as important supporting tools.

Multi-criteria decision-making/multi-criteria decision analysis (with multiple-criteria decision-making/multiple-criteria decision analysis being the alternative terms also in use) is a well-known and a well-developed branch of operational research that encompasses various techniques and mathematical tools, which all facilitate the analysis and selection of decision-making alternatives against the pre-defined criteria. What's important, it is an interdisciplinary branch that is based not only on mathematics, but also takes advantage of the theory of economics and IT [9].

The subject matter literature describes various methods and their classification. In general, MCDM methods can be divided into two categories: discrete MADM (multi-attribute decision-making) and continuous MODM (multi-objective decision-making) [10,11]. According to Dytczak, the two fundamental trends should be identified within MCDM: MCDA and MODM. MODM allows for the creation of a set of decision-making alternatives by using mathematical programming. MCDA methods can be divided into aggregation (most well-known methods include the AHP method and its extensions and the MAUT (multi-attribute utility theory) method), as well as surpassing methods (ELECTRE (elimination and choice expressing the reality) and PROMETHEE (preference organization method ranking for enrichment evaluations) families of methods). Because of the diversity and continuous development of the methods, a third group of the so-called remaining methods can be distinguished. These group encompasses the following methods: geometric distance methods (mostly TOPSIS and VIKOR (VlseKriterijuska Optimizacija I Komoromisno Resenje)), interactive (e.g., RUBIS) or methods of verbal decision analysis (e.g., ZAPROS) [12]. A similar classification was also proposed by Kobryń, who added simple ranking methods, such as Bordy, Arrow-Raynaud, or Copeland methods [13].

As proven by overview works e.g., [9,14,15], MCDM/MCDA methods can constitute a universal tool for supporting the decision-making processes in various fields of life and science. It is worth mentioning that the selected methods are increasingly used in architectural design and urban planning, as well as in construction (see examples of the applications in Tables 1 and 2 in the next part of the work). The interest in this subject is growing systematically, which can be confirmed by the already-delivered general overview work, as well as work focused solely on decision-making challenges in the field of construction $[11,16]$.

In this paper, an overview of the MCDM/MCDA methods applied to the selected decision-making challenges in the field of architecture and urban planning as well as construction was carried out. The analysis was narrowed down to issues pertaining to energy-efficient construction. Special attention was paid to decision-making challenges connected to sustainable development paradigms in the selected fields. Moreover, the second part of the work was devoted to AHP method and its modification (FAHP), which most frequently appeared in the overview. A comparative analysis of these methods was carried out. The numerical example concerned the location of single-family residential building with renewable energy sources, and three scales were used in the calculations, including two fuzzy triangular scales.

The primary goal of this paper is to present the application potential of MCDM/MCDA methods in the field of architecture, urban planning, and in energy-efficient construction, while indicating the most popular methods and research problems. This paper consists of four fundamental parts: introduction, literature overview, and a case study presenting the comparative analysis of AHP and Fuzzy AHP. The paper is concluded with the discussion and conclusions that take into consideration the future research directions. 
Table 1. Examples of the applications of selected MCDM/MCDA (multi-criteria decision-making/multi-criteria decision analysis) methods in architecture and urban planning.

\begin{tabular}{|c|c|c|c|}
\hline Author(s) (year) & The Place of the Case Study & The Selected Method(s) & The Main Subject of the Research \\
\hline $\begin{array}{l}\text { Tamosaitiene J., Sipalis J., Banaitis A., } \\
\text { Gaudutis E. (2013) [17] }\end{array}$ & Vilnius (Lithuania) & $\begin{array}{c}\text { SAW } \\
\text { (Simple Additive Weighting) }\end{array}$ & $\begin{array}{l}\text { Model of location assessment for high-rise buildings in the city ( } 8 \text { alternatives and } \\
\qquad 12 \text { criteria were taken into consideration). }\end{array}$ \\
\hline $\begin{array}{l}\text { Bielinskas V., Burinskiene M., Palevicius } \\
\text { V. (2015) [18] }\end{array}$ & Vilnius (Lithuania) & COPRAS & $\begin{array}{l}\text { Identifying assessment indicators for neglected areas in the city (finally, a set of } 15 \\
\text { indicators related to the selected economic, social, spatial, and environmental } \\
\text { aspects was proposed). }\end{array}$ \\
\hline De Toro P., Iodice S. (2016) [19] & Cava De' Tirreni in Salerno (Italy) & PROMETHEE & $\begin{array}{l}\text { Multi-criteria decision-making support for the selection of Operational Plans ( } 3 \\
\text { alternatives assessed against } 29 \text { defined criteria). }\end{array}$ \\
\hline Ogrodnik K. (2017) [20] & $\begin{array}{l}\text { Bialystok } \\
\text { Chorzow } \\
\text { Czestochowa } \\
\text { Lublin (Poland) }\end{array}$ & PROMETHEE & $\begin{array}{c}\text { Assessment of sustainable development of the selected Polish cities against } 66 \\
\text { quantitative indicators. }\end{array}$ \\
\hline $\begin{array}{l}\text { Zinatizadeh S., Azmi A., Monavari S.M., } \\
\text { Sobhanardakani S. (2017) [21] }\end{array}$ & Kermanshah (Iran) & $\begin{array}{l}\text { SAW } \\
\text { ELECTRE } \\
\text { TOPSIS }\end{array}$ & $\begin{array}{l}\text { Assessment of sustainable development in selected urban areas ( } 6 \text { selected areas } \\
\text { were assessed against } 44 \text { indicators divided into } 3 \text { groups: social and welfare, } \\
\text { economic growth, environmental protection). }\end{array}$ \\
\hline $\begin{array}{c}\text { Pujadas P., Pardo-Bosch F., } \\
\text { Aguado-Renter A., Aguado A. (2017) [22] }\end{array}$ & Barcelona (Spain) & $\begin{array}{l}\text { MAUT } \\
\text { AHP }\end{array}$ & $\begin{array}{l}\text { Assessment of public investments ( } 15 \text { heterogeneous public investment projects } \\
\text { were included in the case study). }\end{array}$ \\
\hline Chen C.S., Chiu Y.H., Tsai L.C. (2018) [23] & $\begin{array}{l}\text { Sun Yat-Sen Historical Museum in Taipei } \\
\text { (Taiwan) }\end{array}$ & $\begin{array}{c}\text { ANP } \\
\text { (Analytic Network Process) }\end{array}$ & $\begin{array}{l}\text { Selection of secondary uses for historic building (the decision model includes four } \\
\text { alternative functions of building utilization which were assessed against selected } \\
\text { economic, social, environmental and historical aspects). }\end{array}$ \\
\hline Harputlugil T. (2018) [6] & $\begin{array}{l}\text { the design studios of Department of } \\
\text { Architecture of Cankaya University } \\
\text { (Turkey) }\end{array}$ & AHP & $\begin{array}{l}\text { Assessment of students' architectural designs (the basis for the assessment were } \\
\text { the main decision criteria: functionality, presentation, process, build quality, } \\
\text { innovation and impact, and sub-criteria defined within them). }\end{array}$ \\
\hline $\begin{array}{l}\text { Tian G.D., Zhang H.H., Feng Y.X., Wang } \\
\text { D.Q., Peng Y., Jia H.F. (2018) [24] }\end{array}$ & China & $\begin{array}{c}\text { AHP } \\
\text { GC-TOPSIS (Grey correlation TOPSIS) } \\
\end{array}$ & $\begin{array}{l}\text { Multi-criteria support for selecting green decoration materials (ten kinds of solid } \\
\text { woods were tested against six criteria). }\end{array}$ \\
\hline Masoumi Z., Genderen J.V. (2019) [25] & Zanjan (Iran) & $\begin{array}{l}\text { AHP } \\
\text { TOPSIS }\end{array}$ & $\begin{array}{l}\text { Determining the direction of the city's sustainable development, taking into } \\
\text { account social, economic and environmental perspectives (eventually, the } \\
\text { assessment of the usefulness of urban areas in terms of future development } \\
\text { was performed). }\end{array}$ \\
\hline $\begin{array}{l}\text { Della Spina L., Giorno C., Galati Casmiro } \\
\text { R. (2019) [7] }\end{array}$ & Catanzaro (Italy) & ANP & $\begin{array}{l}\text { Identifying the preferred urban revitalization scenarios (the decision model } \\
\text { consisted of the following levels: objective, strategic criteria included in four } \\
\text { groups, three urban revitalization scenarios and three selected urban areas). }\end{array}$ \\
\hline $\begin{array}{l}\text { Ribera F., Nesticò A., Cucco P., Maselli G. } \\
\text { (2019) [26] }\end{array}$ & Palazzo Genovese in Salerno (Italy) & AHP & $\begin{array}{l}\text { Identification of the best way to utilize historical buildings, taking into account } \\
\text { selected economic, social, cultural and historical-architectural aspects. }\end{array}$ \\
\hline $\begin{array}{l}\text { Pons O., Franquesa J., Amin Hosseini } \\
\text { S.M. (2019) [27] }\end{array}$ & $\begin{array}{l}\text { The Polytechnic University of Catalonia } \\
\text { (Spain) }\end{array}$ & $\begin{array}{l}\text { MIVES (Modelo Integrado de Valor para } \\
\text { una Evaluación Sostenible), AHP, } \\
\text { Knapsack algorithm }\end{array}$ & $\begin{array}{l}\text { Selection of the best set of educational activities to be used in lectures } \\
\text { on architecture. }\end{array}$ \\
\hline
\end{tabular}


Table 2. Examples of using the selected MCDM/MCDA methods in energy-efficient constructions.

\begin{tabular}{|c|c|c|c|}
\hline Author(s) (year) & The Place of the Case Study & The Selected Method(s) & The Main Subject of the Research \\
\hline Yang Y., Li B., Yao R. (2010) [28] & China & group AHP & $\begin{array}{l}\text { Developing a method for identifying and weighing indicators for the energy efficiency assessment of } \\
\text { residential buildings (eventually, } 17 \text { indicators were proposed). }\end{array}$ \\
\hline $\begin{array}{l}\text { Kuzman M.K., Grošelj P., Ayrilmis N., } \\
\text { Zbašnik-Senegačnik M. (2013) [29] }\end{array}$ & Slovenia & AHP & $\begin{array}{l}\text { A comparative analysis of the selected types of passive house construction along with the } \\
\text { identification of key decision-making factors (the study included: solid wood, wood-frame, aerated } \\
\text { concrete and brick). }\end{array}$ \\
\hline Siozinyte E., Antucheviciene J. (2013) [30] & $\begin{array}{l}\text { the vernacular dwelling from } \\
\text { Aukštaitija region (Lithuania) }\end{array}$ & $\begin{array}{c}\text { AHP } \\
\text { COPRAS } \\
\text { TOPSIS } \\
\text { WASPAS } \\
\text { (Weighted Aggregates Sum Product Assessment) }\end{array}$ & $\begin{array}{l}\text { Multi-criteria analysis of insolation improvements in a vernacular building (three variants and six } \\
\text { criteria were included). }\end{array}$ \\
\hline $\begin{array}{l}\text { Ruzgys A.,, Volvaciovas R., Ignatavicius C., } \\
\text { Turskis Z. (2014) [31] }\end{array}$ & $\begin{array}{l}\text { residential buildings in Vilnius } \\
\text { and Siauliai (Lithuania) }\end{array}$ & $\begin{array}{c}\text { SWARA } \\
\text { (Step-wise Weight Assessment Ratio Analysis) } \\
\text { TODIM } \\
\text { (an acronym in Portuguese of Interactive and } \\
\text { Multi-criteria decision-making) }\end{array}$ & $\begin{array}{l}\text { Evaluation of six cases of residential building modernization along with identifying key factors } \\
\text { affecting the efficiency of this process. }\end{array}$ \\
\hline $\begin{array}{l}\text { Siozinyte E., Antucheviciene J., Kutut V. (2014) } \\
\text { [32] }\end{array}$ & $\begin{array}{l}\text { the vernacular dwelling from } \\
\text { Aukštaitija region (Lithuania) }\end{array}$ & $\begin{array}{l}\text { TOPSIS Grey } \\
\text { AHP }\end{array}$ & $\begin{array}{l}\text { Selection of the best modernization method for an old vernacular building (nine variants and ten } \\
\text { criteria included). }\end{array}$ \\
\hline $\begin{array}{l}\text { Medineckiene M., Dziugaite-Tumeniene R. } \\
\text { (2014) [33] }\end{array}$ & $\begin{array}{l}\text { an existing low energy } \\
\text { individual family house in } \\
\text { Vilnius (Lithuania) }\end{array}$ & $\begin{array}{l}\text { AHP } \\
\text { WASPAS } \\
\text { TOPSIS }\end{array}$ & $\begin{array}{l}\text { Selection of the optimal combination of technologies for a building energy system, taking into account } \\
\text { economic and ecological aspects (five decision alternatives were subject to analysis). }\end{array}$ \\
\hline Chen L., Pan W. (2015) [34] & $\begin{array}{l}\text { high-rise commercial buildings } \\
\text { in Hong Kong (China) }\end{array}$ & Fuzzy PROMETHEE & $\begin{array}{l}\text { Development of a fuzzy MCDM model integrated with BIM for the selection of Low-Carbon Building } \\
\text { (LCB) indicators (five criteria and nine alternatives identified). }\end{array}$ \\
\hline $\begin{array}{l}\text { Sedláková A., Vilč̌eková S., Krídlová Burdová } \\
\text { E. (2015) [35] }\end{array}$ & single-family house in Slovakia & $\begin{array}{c}\text { CDA } \\
\text { (concordance discordance analysis) } \\
\text { IPA } \\
\text { (ideal points analysis) } \\
\text { WSA } \\
\text { (the weighted sum approach) } \\
\text { TOPSIS } \\
\end{array}$ & $\begin{array}{l}\text { Assessment of materials for designing the construction details of the foundations, walls and floors in } \\
\text { the light of environmental and thermophysical criteria. }\end{array}$ \\
\hline $\begin{array}{l}\text { Motuziene A., Rogoza A., Lapinskiene V., } \\
\text { Vilutiene T. (2016) [36] }\end{array}$ & $\begin{array}{l}\text { energy efficient single-family } \\
\text { house in Lithuania }\end{array}$ & $\begin{array}{l}\text { AHP } \\
\text { COPRAS }\end{array}$ & $\begin{array}{l}\text { Development of an algorithm for choosing the most rational design solution, using LCA (life cycle } \\
\text { assessment), LCC (life cycle cost) and the selected MCDA methods (three types of envelopes: masonry, } \\
\text { log, and timber frame of an energy efficient building were subject to this analysis). }\end{array}$ \\
\hline Vujošević M.L., Popović M.J. (2016) [37] & $\begin{array}{l}\text { the atrium type hotel buildings } \\
\text { in Belgrade (Serbia) }\end{array}$ & $\begin{array}{l}\text { PROMETHEE } \\
\text { Borda }\end{array}$ & $\begin{array}{l}\text { Energy performance comparative analysis for atrium-type hotel buildings (four alternatives were } \\
\text { considered, looking for the most energy-efficient atrium hotel model for a selected climate zone). }\end{array}$ \\
\hline Tomczak K., Kinash O. (2016) [38] & $\begin{array}{l}\text { detached family house in } \\
\text { Cracow (Poland) }\end{array}$ & AHP & $\begin{array}{l}\text { Technical and economic analysis of selected construction and building variants of an energy-efficient } \\
\text { building (three alternatives were analyzed). }\end{array}$ \\
\hline $\begin{array}{l}\text { Seddiki M., Anouche K., Bennadji A., Boateng P. } \\
\text { (2016) [39] }\end{array}$ & $\begin{array}{l}\text { neoclassical colonial collective } \\
\text { building in Oran (Algeria) }\end{array}$ & $\begin{array}{c}\text { Delphi } \\
\text { Swing } \\
\text { PROMETHEE }\end{array}$ & $\begin{array}{l}\text { Multi-criteria decision support of a thermal renovation project for a masonry building (selected } \\
\text { renovation solutions were subject to analysis). }\end{array}$ \\
\hline
\end{tabular}


Table 2. Cont

\begin{tabular}{|c|c|c|c|}
\hline Author(s) (year) & The Place of the Case Study & The Selected Method(s) & The Main Subject of the Research \\
\hline $\begin{array}{l}\text { Zavadskas E.K., Antucheviciene J., Kalibatas D., } \\
\text { Kalibatiene D. (2017) [40] }\end{array}$ & $\begin{array}{l}\text { apartments in brick dwelling } \\
\text { houses in Vilnius (Lithuania) }\end{array}$ & $\begin{array}{c}\text { WASPAS } \\
\text { ARAS } \\
\text { (Additive Ratio Assessment) } \\
\text { TOPSIS }\end{array}$ & $\begin{array}{l}\text { Assessment of the condition of buildings along with comparative analysis with the optimal alternative, } \\
\text { i.e., nearly zero-energy building (NZEB) (the case study pertained to } 13 \text { apartments). }\end{array}$ \\
\hline $\begin{array}{l}\text { Cortes J.P.R., Ponz-Tienda J.L., Delgado J.M., } \\
\text { Gutierrez-Bucheli L. (2017) [41] }\end{array}$ & $\begin{array}{l}\text { a new University's facility } \\
\text { construction in Colombia }\end{array}$ & CBA (Choosing By Advantages) & Selection of a structural contractor (four alternatives were subject to analysis). \\
\hline $\begin{array}{l}\text { Guzman-Sanchez S., Jato-Espino D., Lombillo I., } \\
\text { Diaz-Sarachaga J.M. (2018) [42] }\end{array}$ & $\begin{array}{c}\text { Valencia } \\
\text { Santander } \\
\text { Madrid (Spain) }\end{array}$ & $\begin{array}{l}\text { AHP } \\
\text { TOPSIS }\end{array}$ & $\begin{array}{l}\text { Assessment of the selected roof types in terms of sustainable development requirements (analyzed in } \\
\text { the following order: self-protected, gravel finishing, floating flooring and green; the analysis was } \\
\text { performed for three climate scenarios). }\end{array}$ \\
\hline $\begin{array}{l}\text { Moghtadernejad S., Chouinard L.E., Mirza M.S. } \\
\text { (2018) [43] }\end{array}$ & Canada & $\begin{array}{c}\text { AHP } \\
\text { Choquet TOPSIS }\end{array}$ & $\begin{array}{l}\text { Multi-criteria sustainable facade design (four facade panel alternatives were assessed: concrete, } \\
\text { aluminum-glazing, fiber cement composite and sandwich panels against eight criteria). }\end{array}$ \\
\hline $\begin{array}{l}\text { Zolfani S.H., Pourhossein M., Yazdani M., } \\
\text { Zavadskas E.K. (2018) [44] }\end{array}$ & five-star hotel in Tehran (Iran) & $\begin{array}{l}\text { SWARA } \\
\text { COPRAS }\end{array}$ & $\begin{array}{l}\text { Assessment of hotel projects in terms of sustainable development (five different project alternatives } \\
\text { were subject to a multi-criteria analysis). }\end{array}$ \\
\hline $\begin{array}{l}\text { Arroyo P., Mourgues C., Flager F., Correa M.G. } \\
\text { (2018) [45] }\end{array}$ & $\begin{array}{l}\text { hotel building in Orlando, } \\
\text { Florida (USA) }\end{array}$ & СВА & $\begin{array}{l}\text { Selection of a design solution (the study included } 1000 \text { different alternatives based on different } \\
\text { combinations of design variables). }\end{array}$ \\
\hline $\begin{array}{l}\text { Jalilzadehazhari E., Vadiee A., Johansson P. } \\
\text { (2019) [8] }\end{array}$ & Sweden & AHP & $\begin{array}{l}\text { Selection of a construction solution (the study included } 375 \text { different alternatives based on different } \\
\text { combinations of design variables). }\end{array}$ \\
\hline Beltran R.D., Martinez-Gomez J. (2019) [46] & social dwelling in Ecuador & $\begin{array}{l}\text { COPRAS-G } \\
\text { (COPRAS-Gray) } \\
\text { TOPSIS } \\
\text { VIKOR }\end{array}$ & $\begin{array}{l}\text { Phase change materials (PCM) analysis for the purpose of constructing wall panels and roofs (nine } \\
\text { alternative building materials included). }\end{array}$ \\
\hline
\end{tabular}

Source: author's own work. 


\section{Materials and Methods}

\subsection{MCDM/MCDA in Architecture, Urban Planning and Energy-Efficient Construction: Literature Review}

As a result of the undertaken literature studies, Tables 1 and 2 present examples of previous applications of the MCDM/MCDA methods for the selected decision-making challenges in the field of architecture, urban planning, and energy-efficient constructions. What is important, selected scientific papers which are indexed in the Web of Science and Scopus databases were assumed as the basis for this elaboration. The developed list is the result of a several-stage analysis of scientific papers in the abovementioned databases. In the first stage, a preliminary selection of articles available in databases was made, using keywords: "MCDM/MCDA in architecture," "MCDM/MCDA in urban planning," "MCDM/MCDA in energy-efficient construction." Then, selected scientific papers were analyzed in terms of criteria which result from the main purpose of the work. Only the research in which the research problem and the methods applied were precisely determined and the territorial delimitation of research was defined, was selected.

The research is presented chronologically, divided into examples of applications in architecture and urban planning (Table 1) and in energy-efficient construction (Table 2). The literature review included 33 publications.

Based on the literature review, it can be noticed that MCDM/MCDA methods are universal tools, which is confirmed by the variety of decision-making challenges presented in Tables 1 and 2 . In architecture and urban planning, the selected methods are applied-for example-at the stage of selecting urban revitalization scenarios and for renovation of historical buildings. In addition, assessing sustainable development of urban areas is a popular research topic. MCDM/MCDA methods are also gaining popularity in energy-efficient construction, in which the selection of a design solution often requires one to take into consideration many criteria of different nature. In addition to technical criteria, economic and environmental criteria often occur; a phenomenon that stems from the sustainable development paradigm.

It is also worth mentioning the effectiveness of selected MCDM/MCDA methods. Based on the literature review, it can be stated that the selected methods facilitate decomposition of the decision problem, improve the transparency of decision processes, facilitate comparison of various decision alternatives, identify their strengths and weaknesses [19,29]. However, in addition to the advantages, some authors also noted the weaknesses and limitations of selected MCDM/MCDA methods. For example, Moghtadernejad et al. among the limitations of the AHP and TOPSIS methods (method which were used in their case study) indicate the lack of consideration of interactions between various design criteria [43]. In contrast, Zinatizadeh et al. compared three selected methods: SAW, ELECTRE and TOPSIS, where the TOPSIS method came out best. Other methods, SAW and ELECTRE, were rated lower, e.g., in terms of ability in pair comparison or ability to manage low quality input data [21]. In the work of multi-criteria decision support of a thermal renovation project for a masonry building, the authors used the Delphi, Swing, and PROMETHEE methods, indicating their several limitations, e.g., the method did not take into account the various uncertainties (regarding the assessment of criteria or decision makers' preferences) that could have influenced the final ranking of decision variants [39]. More about the pros and cons of selected MCDM/MCDA methods can be found in works [47,48]. It is worth adding that because of the limitations of individual methods, the hybrid approach is becoming increasingly popular, Zavadskas et al. state that "to have comprehensive assessment, it is better to use two or three different MCDM" [40].

MCDM/MCDA methods are not only universal, but also well-known tools, as evidenced by territorial delimitation of the conducted research. Figure 1 presents places where research focused on the subject of multi-criteria decision support was carried out. The major research centers in this field are Europe (primarily Lithuania, followed by Spain, Italy, and Poland), Asia, and both the Middle and the Far East (Iran and China) (compare: [3]). 


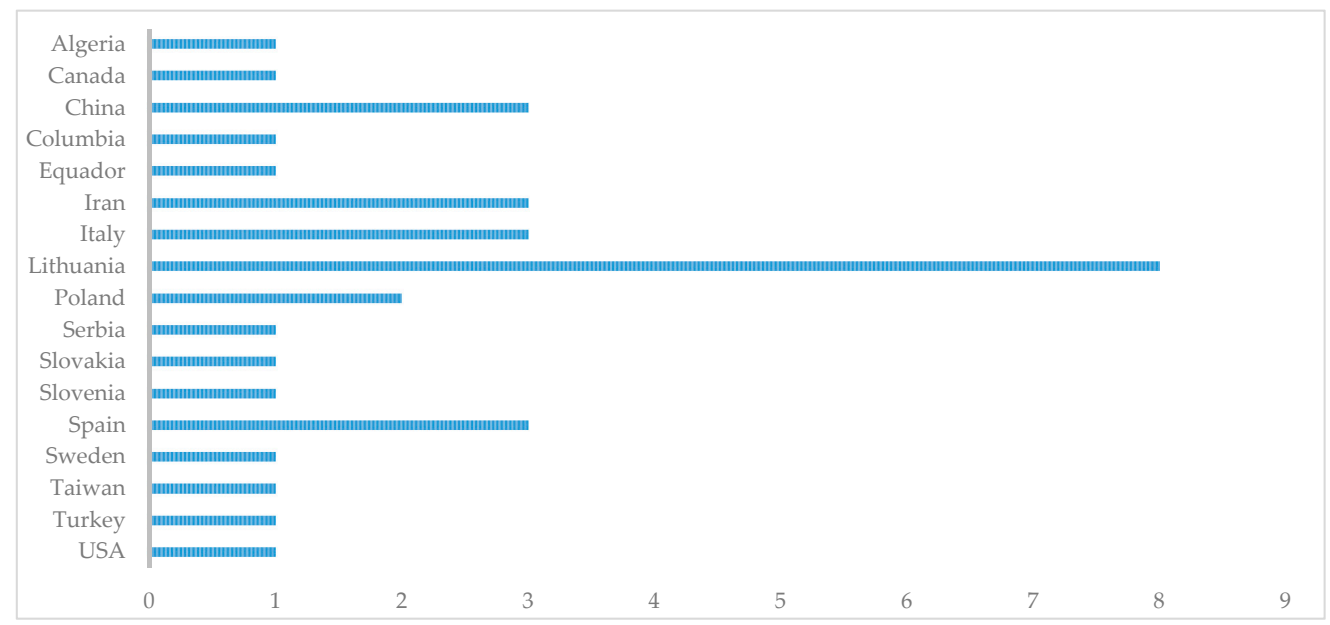

Figure 1. Countries in which selected studies on MCDM/MCDA were carried out with the focus on architecture and urban planning, as well as in the area of energy-efficient construction. Source: author's own work.

In addition, when analyzing the methods used in the selected papers, it can be seen that the most commonly used method was AHP and its extensions. The AHP method appeared in 16 papers included in the literature overview. Importantly, the AHP method was most often used to calculate the weighted criteria, which were then used to rank decision variants using other methods, e.g., TOPSIS. In addition, research conducted to-date shows that MCDM/MCDA methods can be combined by using the so-called hybrid approach, which allows one to increase the efficiency of the adopted methods. The AHP and TOPSIS hybrid is the most popular combination. A conjunction with the COPRAS method is also increasingly applied. It is worth adding that MCDM/MCDA methods can be integrated with other methods and systems, such as the dynamically developing BIM (building information modeling) system or the GIS (geographic information system) system.

The AHP method, which—for many years now — has been subject to significant interest in many areas around the world see for example: [49,50], is also being considered in terms of its advantages and disadvantages. Among the advantages of the AHP method the following can be mentioned: decomposition of a decision problem using a hierarchical structure tree, the possibility of making comparisons through element pairs that are located at given levels of the structure, the possibility of assessing the consistency of the comparisons by using consistency ratio. The AHP algorithm is also subject to criticism, for example: the independence of the analyzed elements, excessive subjectivity, or difficulty of accounting for uncertainties associated with judgments [43,51].

MCDM/MCDA methods are constantly evolving, and that is why fuzzy multi-criteria methods are becoming an important and equally popular group of computational tools. The most commonly used method is Fuzzy AHP, which dates back to 1983 [52]. The next part of this paper presents this method's algorithm that is subsequently used to develop a case study.

\subsection{Fuzzy AHP-Algorithm and Selected Scales}

The fuzzy sets theory was first presented in the 1960s by Zadeh, as a mathematical method to facilitate the framing of uncertainty and imprecision, which often accompanies human assessments. In the 1970s, the fuzzy sets theory also appeared within the scope of decision-making challenges. As mentioned in the previous section, the most commonly used method is the Fuzzy AHP method (abbreviated FAHP). Among the researchers who contributed to the development of FAHP are: van Laarhoven and Pedrycz, Buckley, and Chang [53,54]. Importantly, this work uses a known algorithm proposed by Buckley. Individual FAHP calculation steps are shown in Figure 2. 


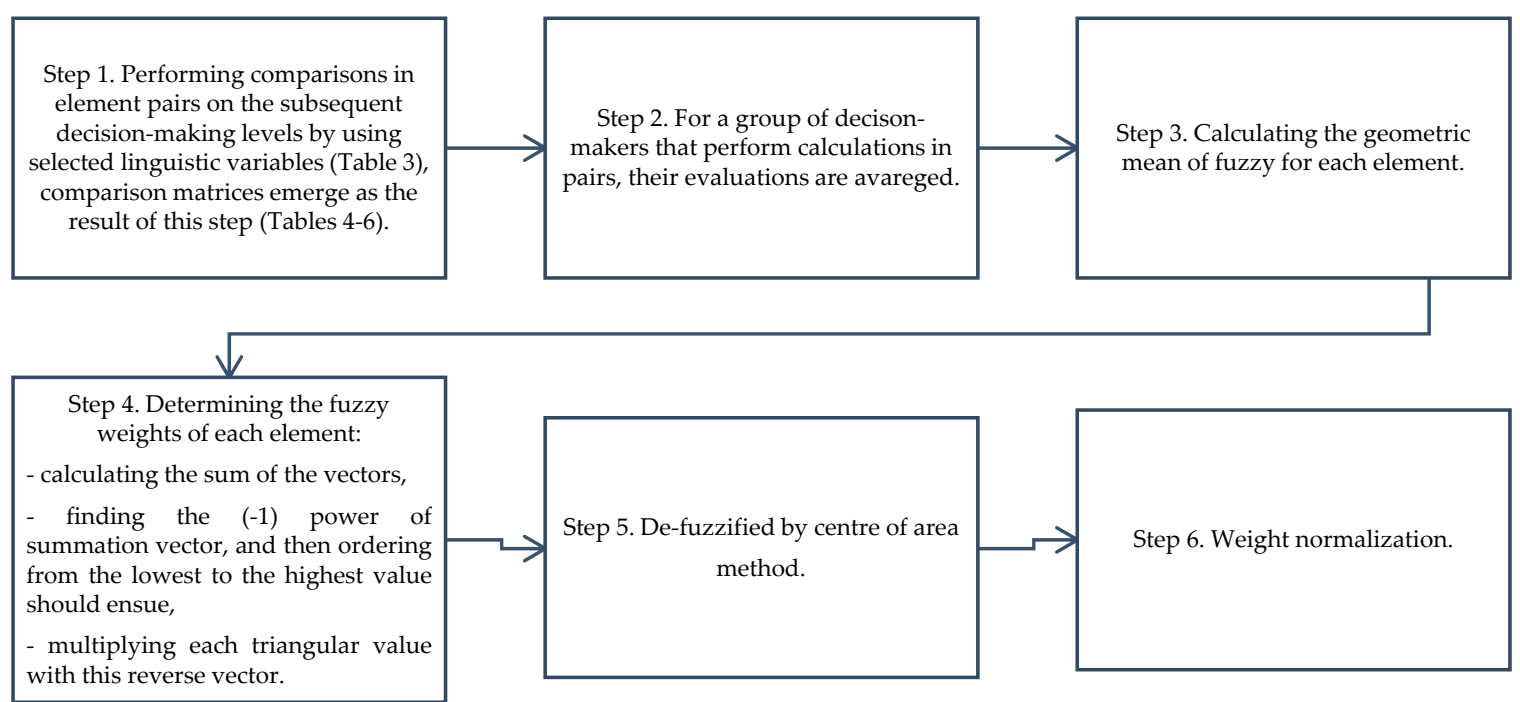

Figure 2. Main calculation stages of Fuzzy AHP. Source: author's own work based on [54].

Importantly, the literature on the subject matter quotes various scales used in FAHP (e.g., in online output software application, the user has a choice of nine different scales) [59]. In this paper, in addition to the classic Saaty scale, two fuzzy triangular scales (Table 3) were used. Calculation results and comparative analysis of weights obtained by using individual scales are presented in the subsequent part of this paper.

Table 3. Classic Saaty scale and selected Fuzzy triangular scales.

\begin{tabular}{cccc}
\hline Definition & Classic Saaty Scale & $\begin{array}{c}\text { Fuzzy Triangular } \\
\text { Scale-Variant I }\end{array}$ & $\begin{array}{c}\text { Fuzzy Triangular } \\
\text { Scale-Variant II }\end{array}$ \\
\hline Equal Importance & 1 & $1,1,1$ & $1,1,1$ \\
Weak or slight & 2 & $1,2,3$ & $1,2,4$ \\
Moderate importance & 3 & $2,3,4$ & $1,3,5$ \\
Moderate plus & 4 & $3,4,5$ & $2,4,6$ \\
Strong importance & 5 & $4,5,6$ & $3,5,7$ \\
Strong plus & 6 & $5,6,7$ & $4,6,8$ \\
Very strong & 7 & $6,7,8$ & $5,7,9$ \\
Very, very strong & 8 & $7,8,9$ & $6,8,9$ \\
Extremely strong & 9 & $9,9,9$ & $7,9,9$ \\
\hline
\end{tabular}

Source: [54-58].

\section{Results}

The subject of this research is a comparative analysis of the weights for the location criteria of residential area with solar installations and obtained via the classical AHP method [60] with the weights of these criteria, calculated by means of the Fuzzy AHP method (two fuzzy scales included). The assessment of the suitability of the area for residential development with solar installations can be considered as a multi-criteria decision problem. Selecting the location for this type of investment is the net sum of not only spatial, environmental, or legal conditions, but the inhabitants' preferences also play a key part in that decision-making process. For that reason, the excessive subjectivity (of which AHP and FAHP methods are often accused), may be its advantage in the case of such decision-making challenges. Importantly, the decision-making criteria used for the case study are the result of research described in the following papers $[60,61]$. 


\subsection{Hierarchical Structure Tree}

The basis of the hierarchical structure tree (Figure 3) was a set of criteria proposed in the papers on assessment of area in terms of the location of single-family residential buildings with solar installations [60,61]. Importantly, the groups of criteria and main criteria were developed on the basis of the subject matter literature review i.e., [62-64] and selected legal provisions. Fifteen main criteria were proposed, taking into account the distance from selected facilities, properties of plots. Moreover, selected climatic factors likely to affect the efficiency of solar installations have been taken into consideration. The last decision level, i.e., sub-criteria have local character and depends on the research area, the subcriteria of these figure were proposed on the basis of spatial analysis of Bialystok.

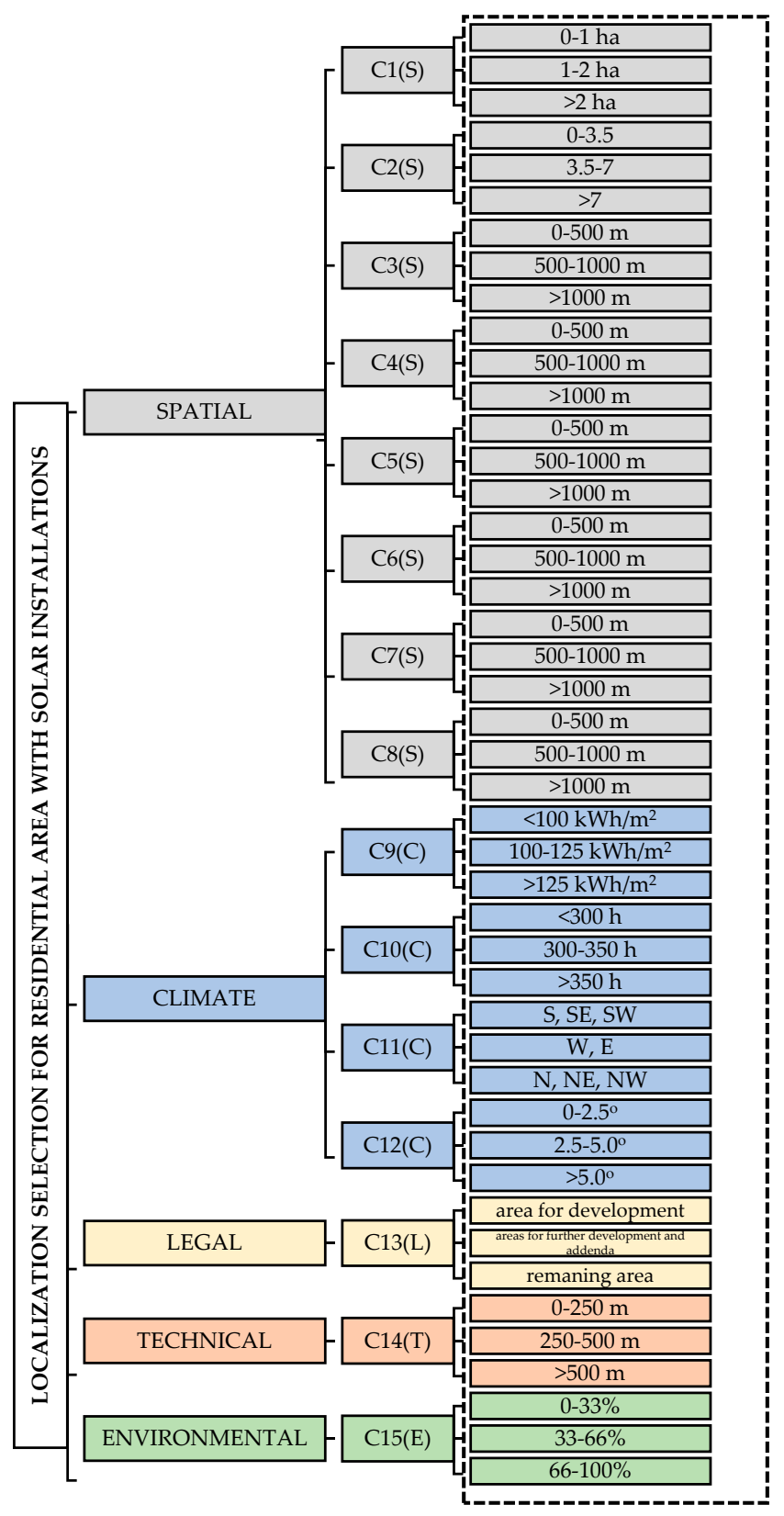

Figure 3. Hierarchical structure tree. * The last decision level (in frame) depends on the research area; the subcriteria of these figure were proposed on the basis of spatial analysis of Bialystok. Source: author's own work based on $[60,61]$.

A hierarchical structure tree was developed, in which the following levels were distinguished: 
- Purpose: location of residential buildings with solar installations;

- Groups of criteria: spatial (S), climate (C), legal (L), technical (T), environmental (E);

- Main criteria: plot area C1(S), plot shape C2(S), distance from education facilities C3(S), distance from healthcare facilities $\mathrm{C} 4(\mathrm{~S})$, distance from commercial and service facilities $\mathrm{C5}(\mathrm{S})$, distance from bodies of forest $\mathrm{C} 6(\mathrm{~S})$, distance from sports and recreation areas $\mathrm{C} 7(\mathrm{~S})$, distance from places of worship $\mathrm{C} 8(\mathrm{~S})$, total insolation $\mathrm{C} 9(\mathrm{C})$, duration of sunlight exposure $\mathrm{C} 10(\mathrm{C})$, exposure of the area $\mathrm{C} 11(\mathrm{C})$, sloping $\mathrm{C} 12(\mathrm{C})$, purpose in urban planning $\mathrm{C} 13(\mathrm{~L})$ (in the case of Poland it is a study of conditions and directions of spatial development), accessibility of communication infrastructure C14(T), degree of plot forestation C15(E);

- Sub-criteria-constituting the ranges defined within individual main criteria, they are local in character and are determined by the conditions of the given area.

Importantly, the groups of criteria presented in Figure 3, main criteria and sub-criteria, the hierarchical structure tree presents only the so-called soft criteria, i.e., factors enabling the suitability assessment of a given area in terms of the location of the selected investment.

\subsection{Comparison Matrices}

A series of pairwise comparisons of individual elements was subsequently made at each decision-making level (Tables 4-6 show comparison matrices for groups of criteria developed by using three different scales).

Table 4. Comparison matrix for criteria groups (classic Saaty's scale).

\begin{tabular}{cccccc}
\hline & Spatial & Climate & Legal & Technical & Environmental \\
\hline Spatial & 1 & 3 & 5 & 7 & 9 \\
Climate & $1 / 3$ & 1 & 3 & 5 & 7 \\
Legal & $1 / 5$ & $1 / 3$ & 1 & 3 & 5 \\
Technical & $1 / 7$ & $1 / 5$ & $1 / 3$ & 1 & 3 \\
Environmental & $1 / 9$ & $1 / 7$ & $1 / 5$ & $1 / 3$ & 1 \\
\hline \multicolumn{7}{c}{ Source: author's own work. }
\end{tabular}

Table 5. Comparison matrix for criteria groups (Fuzzy triangular scale-variant I).

\begin{tabular}{|c|c|c|c|c|c|c|c|c|c|c|c|c|c|c|c|}
\hline \multirow[b]{2}{*}{ Spatial } & \multicolumn{3}{|c|}{ Spatial } & \multicolumn{3}{|c|}{ Climate } & \multicolumn{3}{|c|}{ Legal } & \multicolumn{3}{|c|}{ Technical } & \multicolumn{3}{|c|}{ Environmental } \\
\hline & 1 & 1 & 1 & 2 & 3 & 4 & 4 & 5 & 6 & 6 & 7 & 8 & 9 & 9 & 9 \\
\hline Climate & $1 / 4$ & $1 / 3$ & $1 / 2$ & 1 & 1 & 1 & 2 & 3 & 4 & 4 & 5 & 6 & 6 & 7 & 8 \\
\hline Legal & $1 / 6$ & $1 / 5$ & $1 / 4$ & $1 / 4$ & $1 / 3$ & $1 / 2$ & 1 & 1 & 1 & 2 & 3 & 4 & 4 & 5 & 6 \\
\hline Technical & $1 / 8$ & $1 / 7$ & $1 / 6$ & $1 / 6$ & $1 / 5$ & $1 / 4$ & $1 / 4$ & $1 / 3$ & $1 / 2$ & 1 & 1 & 1 & 2 & 3 & 4 \\
\hline Environmental & $1 / 9$ & $1 / 9$ & $1 / 9$ & $1 / 8$ & $1 / 7$ & $1 / 6$ & $1 / 6$ & $1 / 5$ & $1 / 4$ & $1 / 4$ & $1 / 3$ & $1 / 2$ & 1 & 1 & 1 \\
\hline
\end{tabular}

Table 6. Comparison matrix for criteria groups (Fuzzy triangular scale—variant II).

\begin{tabular}{|c|c|c|c|c|c|c|c|c|c|c|c|c|c|c|c|}
\hline \multirow[b]{2}{*}{ Spatial } & \multicolumn{3}{|c|}{ Spatial } & \multicolumn{3}{|c|}{ Climate } & \multicolumn{3}{|c|}{ Legal } & \multicolumn{3}{|c|}{ Technical } & \multicolumn{3}{|c|}{ Environmental } \\
\hline & 1 & 1 & 1 & 1 & 3 & 5 & 3 & 5 & 7 & 5 & 7 & 9 & 7 & 9 & 9 \\
\hline Climate & $1 / 5$ & $1 / 3$ & 1 & 1 & 1 & 1 & 1 & 3 & 5 & 3 & 5 & 7 & 5 & 7 & 9 \\
\hline Legal & $1 / 7$ & $1 / 5$ & $1 / 3$ & $1 / 5$ & $1 / 3$ & 1 & 1 & 1 & 1 & 1 & 3 & 5 & 3 & 5 & 7 \\
\hline Technical & $1 / 9$ & $1 / 7$ & $1 / 5$ & $1 / 7$ & $1 / 5$ & $1 / 3$ & $1 / 5$ & $1 / 3$ & 1 & 1 & 1 & 1 & 1 & 3 & 5 \\
\hline Environmental & $1 / 9$ & $1 / 9$ & $1 / 7$ & $1 / 9$ & $1 / 7$ & $1 / 5$ & $1 / 7$ & $1 / 5$ & $1 / 3$ & $1 / 5$ & $1 / 3$ & 1 & 1 & 1 & 1 \\
\hline
\end{tabular}

Source: author's own work.

\subsection{Comparative Analysis}

Because of the volume of data, the next part of the work presents only the results of pairwise comparisons, i.e., the weight of all the elements at subsequent decision-making levels in three variants (Table 7 and Figures 4 and 5). 
Table 7. Weights of groups of criteria, main criteria and sub-criteria calculated by the AHP and FAHP (Fuzzy AHP) methods.

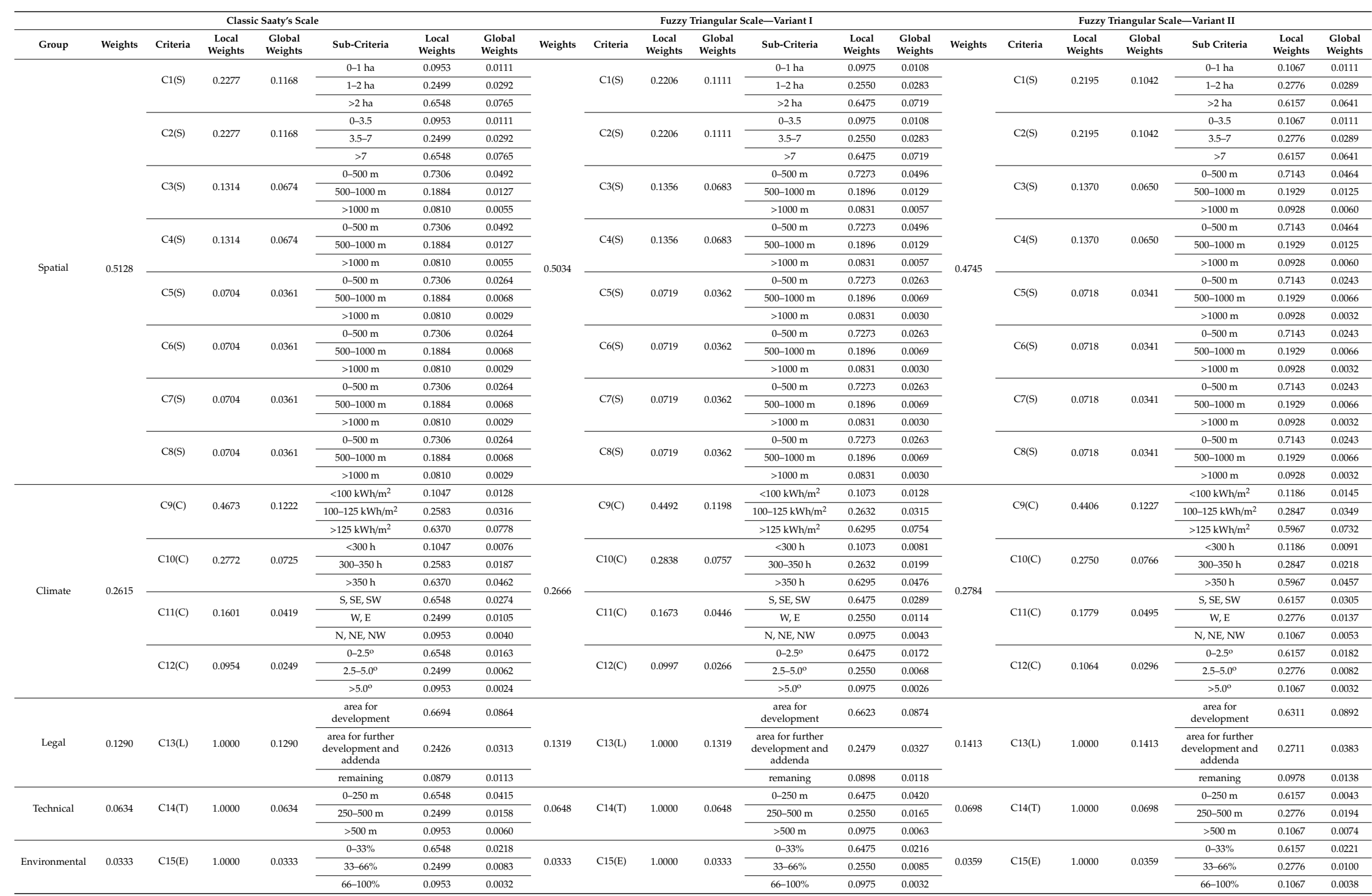




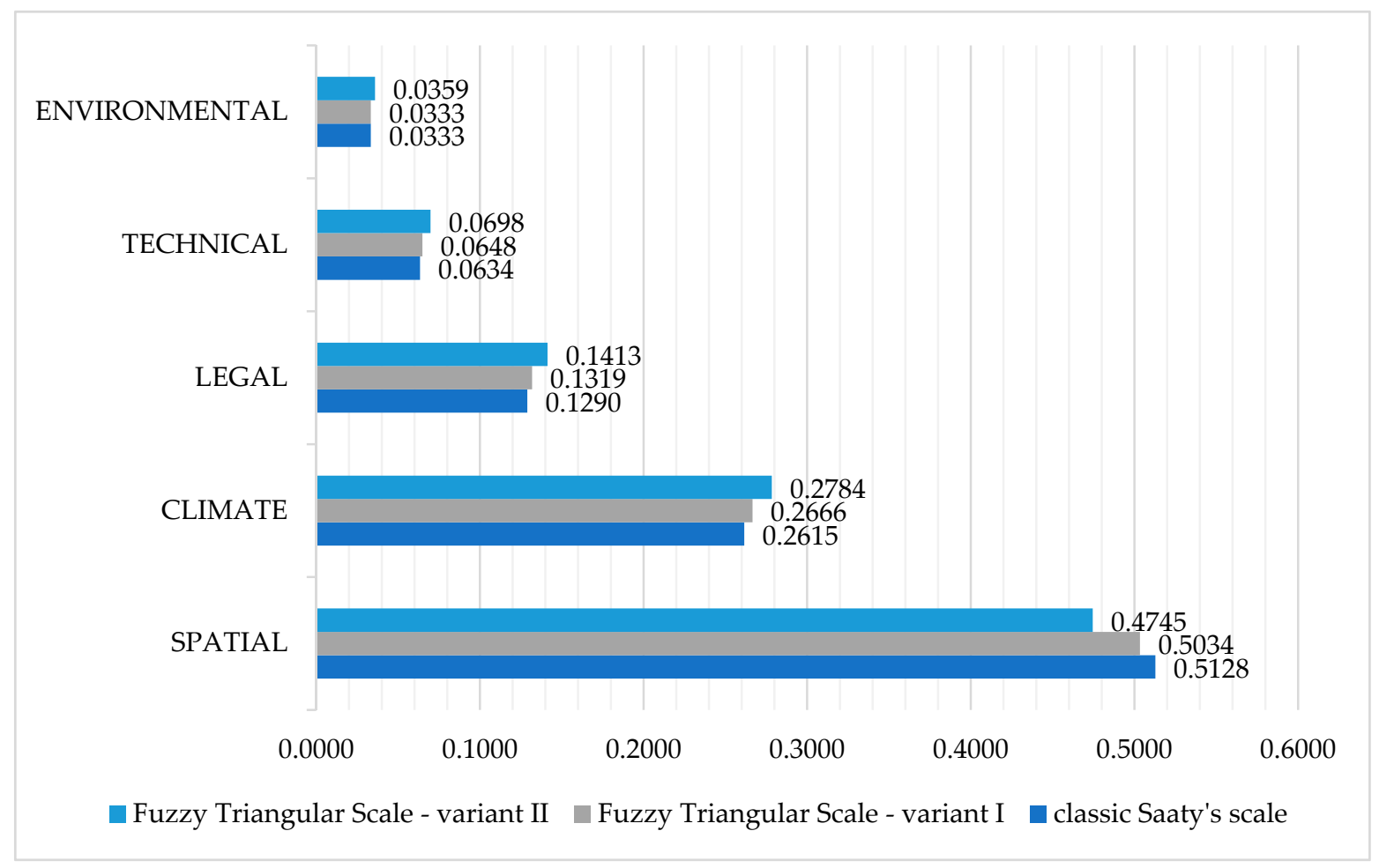

Figure 4. Group weights criteria calculated using three scales. Source: author's own work.

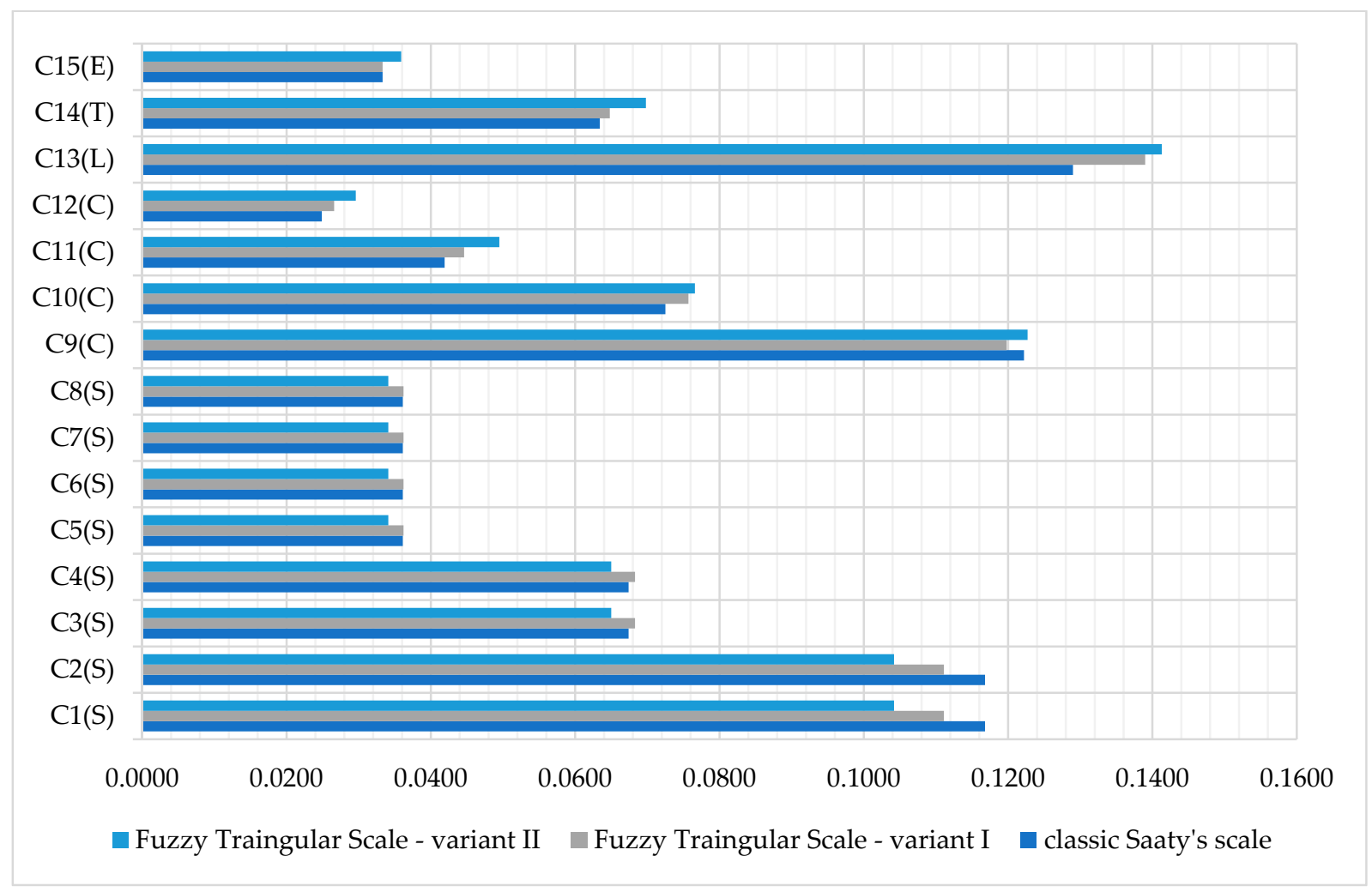

Figure 5. Global weight criteria calculated using three scales. Source: author's own work.

Based on the calculations, it can be stated, that in the case of groups of criteria, regardless of the scale, the group of spatial criteria obtained the highest weight, followed by the group of criteria pertaining to the selected climatic parameters. Relatively lower weights were obtained successively by 
legal, technical, and environmental criteria. The differences between the weights of groups of decision criteria obtained using the classic scale and the first variant of the fuzzy triangular scale were not significant. In the case of group of spatial criteria, this difference was 0.0094, for group of climatic criteria: 0.051 , group of legal criteria: 0.029 , and for group of technical criteria: 0.0014 . The weights of the group of environmental criteria were the same in the both scale (classic scale and the first variant of triangular scale). Slightly higher differences were noted between the weights obtained using the second fuzzy scale, for example in the case of a group of spatial criteria this difference was 0.0383 . Similar properties can be observed at the lower levels of the hierarchical structure.

\section{Discussion}

Based on the results obtained, it can be concluded that the differences between the criteria weights obtained using the classic Saaty's scale and the weights calculated using fuzzy scales, (especially its first variant) are not significant. First of all, despite the application of different scales, the general order of criteria did not change. The global weights of criteria groups influenced the weights of criteria and sub-criteria located at the lower levels of the structure. However, it should be emphasized here that the developed hierarchical structure, together with weights, is only an example aimed at assessing the impact of using different scales (existing in the literature on the subject) on the final set of decision-making factor weights at individual levels.

The FAHP method, just like its classic version, has its advantages and disadvantages. Among the advantages, we should undoubtedly indicate the simplified-from the point of view of the decision-maker-procedure of pairwise comparison, especially in the situation of uncertainty or incomplete information about a given decision-making challenge. On the other hand, it could be considered a certain limitation of FAHP that it operates under a more complicated algorithm when compared to the classical AHP method. The calculation algorithm presented in this paper, based on Buckley's assumptions, is not the only procedure of operation, see [65]. In addition, applying FAHP to more complex decision-making challenges and performing sensitivity analyses without the appropriate computer support significantly increases calculation times.

It should be emphasized that a comparative analysis of the AHP and FAHP methods has already been subject to research, for example during the analysis of the selected decision-making challenges in the food industry [66], resource analysis based on a selected example from the energy industry, [67], supplier selection [68], or a decision-making model that is closest to the subject matter of this paper, i.e., a model in the field of spatial planning [69]. The authors of the aforementioned studies evaluated the application potential of Saaty's method extensions in the context of selected decision-making challenges. In modern times, especially in complex economic conditions where many decisions are accompanied by a level of uncertainty, the MCDM/MCDA methods on fuzzy sets may serve as support tools [65]. According to the authors Kabir Hasin [67], the fuzzy AHP's approach allows for a more accurate description of the decision-making process, allowing one to grasp the vagueness of human thinking. The authors recommend using FAHP if information/evaluations are not certain. On the other hand-in the case of spatial planning and based on their research — the authors stated that: "if the planning aims to identify priority areas for development as a focal point, simpler MCDM methods such as AHP should be sufficient. In this situation, selecting more sophisticated techniques like Fuzzy AHP, which can only be seen as a black box by stakeholders, will not necessarily generate different outcomes" [69] (p. 64).

In summary, both AHP and FAHP have certain limitations. Therefore, the key aspect is correct method selection and adjusting the calculation techniques to the specificity of the decision-making challenge under consideration. In the case of such fields as architecture, urban planning or energy-efficient construction, it is often necessary to take into account the preferences of residents/users of facilities/space. For that reason, the AHP method-together with its extensions - can significantly support the design processes. The algorithm of pairwise comparison, using the traditional Saaty scale, as well as the triangular number scales, can be used when in questionnaire for collecting and assessing 
the preferences of decision-makers see e.g., [70]. Examples of decision-making problems that require research the preferences of residents/users include, e.g., delineation of development areas in the city, identifying the preferred urban revitalization scenarios or selection of the best modernization method. Importantly, there are already practical examples of using the MCDM/MCDA methods, for example for the research of residential preferences in Poznan [71].

\section{Conclusions}

Based on the subject-matter literature studies and the fuzzy multi-criteria analysis, the following conclusions can be made:

- $\quad \mathrm{MCDM} / \mathrm{MCDA}$ methods can serve as effective support tools at the stage when various decisions are being made by engineers. The overview of possible applications, which was elaborated within this paper, can constitute a set of good practices, facilitating the selection of an appropriate method or a set of methods tailored to a specific decision-making challenge;

- $\quad \mathrm{MCDM} / \mathrm{MCDA}$ methods are constantly evolving, with new methods appearing and numerous modifications to the existing ones coming into the picture; the development of fuzzy set theory in multi-criteria decision-making support is also an important research direction;

- The AHP and FAHP methods can be particularly useful when dealing with challenges that require taking into account the preferences of various entities; the popular examples of such challenges within the scope of the analyzed fields are e.g., revitalization models of both entire districts and individual facilities, delimitation and assessment of selected urban areas (developmental, neglected etc.,) or improving the energy efficiency of facilities;

- In a situation when complete information is available, it is recommended to use the classic AHP method that has the advantage of a simpler algorithm and wide variety of available computer programs that can perform the analysis; the example from the elaborated case study and the results of previous studies show that the differences between the weights obtained using AHP and FAHP are not significant;

- The AHP method and its extensions are some of the most popular methods that enable weighting of decision-making factors, but it is not the only one; therefore, among future research directions, one can indicate a comparative analysis of AHP modifications with other methods, e.g., SWARA method.

Funding: The research has been completed within the research project WZ/WBiIŚ/6/2019 and financed by public funds of Polish Ministry of Science and Higher Education.

Conflicts of Interest: The author declare no conflict of interest.

\section{References}

1. Bossel, H. Indicators for Sustainable Development: Theory, Method, Applications; A Report to the Balaton Group; International Institute for Sustainable Development: Winnipeg, MB, Canada, 1999.

2. International Institute for Sustainable Development. Available online: https://www.iisd.org/ (accessed on 14 October 2019).

3. Zavadskas, E.K.; Šaparauskas, J.; Antucheviciene, J. Sustainability in Construction Engineering. Sustainability 2018, 10, 2236. [CrossRef]

4. Williams, K.; Burton, E.; Jenks, M. Achieving Sustainable Urban. Form: an introduction; Spon Press: London, UK, 2004.

5. Ogrodnik, K. Contemporary concepts of sustainable urban development-selected examples in theory and practice. In Spatial Management in Conditions of Sustainable Development; Broniewicz, E., Ed.; Publishing House of the Bialystok University of Technology: Bialystok, Poland, 2017; pp. 67-84.

6. Harputlugil, T. Analytic Hierarchy Process (AHP) as an Assessment Approach for Architectural Design: Case Study of Architectural Design Studio. Int. J. Archit. Plan. 2018, 6, 217-245. [CrossRef] 
7. Della Spina, L.; Giorno, C.; Galati Casmiro, R. Bottom-Up Processes for Culture-Led Urban Regeneration Scenarios. In Computational Science and Its Applications-ICCSA 2019; Misra, S., Ed.; Lecture Notes in Computer Science; Springer: Berlin/Heidelberg, Germany, 2019; pp. 93-107.

8. Jalilzadehazhari, E.; Vadiee, A.; Johansson, P. Achieving a Trade-Off Construction Solution Using BIM, an Optimization Algorithm, and a Multi-Criteria Decision-Making Method. Buildings 2019, 9, 81. [CrossRef]

9. Behzadian, M.; Otaghsara, S.K.; Yazdani, M.; Ignatius, J. A state-of the-art survey of TOPSIS applications. Expert Syst. Appl. 2012, 39, 13051-13069. [CrossRef]

10. Zavadskas, E.K.; Turskis, Z. Multiple Criteria Decision Making (MCDM) methods in economics: An overview. Technol. Econ. Dev. Econ. 2011, 17, 397-427. [CrossRef]

11. Zavadskas, E.K.; Antucheviciene, J.; Kapliński, O. Multi-criteria decision making in civil engineering: Part I-A state-of-the-art survey. Eng. Struct. Technol. 2015, 7, 103-113. [CrossRef]

12. Dytczak, M. Selected Methods for Multi-Criteria Decision Analysis in Civil. Engineering; Opole University of Technology: Opole, Poland, 2008.

13. Kobryń, A. Multi-Criteria Decision Support in Space Management; Difin: Warsaw, Poland, 2015.

14. Zavadskas, E.K.; Turskis, Z.; Kildienè, S. State of art surveys of overviews on MCDM/MADM methods. Technol. Econ. Dev. Econ. 2014, 20, 165-179. [CrossRef]

15. Emrouznejad, A.; Marra, M. The state of the art development of AHP (1979-2017): A literature review with a social network analysis. Int. J. Prod. Res. 2017, 55, 6653-6675. [CrossRef]

16. Jato-Espino, D.; Castillo-Lopez, E.; Rodriguez-Hernandez, J.; Canteras-Jordana, J.C. A review of application of multi-criteria decision making methods in construction. Autom. Constr. 2014, 45, 151-162. [CrossRef]

17. Tamosaitiene, J.; Sipalis, J.; Banaitis, A.; Gaudutis, E. Complex model for the assessment of the location of high-rise buildings in the city urban structure. Int. J. Strateg. Prop. Manag. 2013, 17, 93-109. [CrossRef]

18. Bielinskas, V.; Burinskienè, M.; Palevičius, V. Assessment of neglected areas in Vilnius city using MCDM and COPRAS methods. Procedia Eng. 2015, 122, 29-38. [CrossRef]

19. De Toro, P.; Iodice, S. Evaluation in urban planning: A multi-criteria approach for the choice of alternative Operational Plans in Cava De' Tirreni. Aestimum 2016, 69, 93-112. [CrossRef]

20. Ogrodnik, K. The application of the PROMETHEE method in evaluation of sustainable development of the selected cities in Poland. Econ. Environ. 2017, 3, 19-36.

21. Zinatizadeh, S.; Azmi, A.; Monavari, S.M.; Sobhanardakani, S. Multi-criteria decision making for sustainability evaluation in urban areas: A case study for Kermanshah City, Iran. Appl. Ecol. Environ. Res. 2017, 15, 1083-1100. [CrossRef]

22. Pujadas, P.; Pardo-Bosch, F.; Aguado-Renter, A.; Aguado, A. MIVES multi-criteria approach for the evaluation, prioritization, and selection of public investment projects. A case study in the city of Barcelona. Land Use Policy 2017, 64, 29-37. [CrossRef]

23. Chen, C.S.; Chiu, Y.H.; Tsai, L. Evaluating the adaptive reuse of historic buildings through multicriteria decision-making. Habitat Int. 2018, 81, 12-23. [CrossRef]

24. Tian, G.; Zhang, H.; Feng, Y.; Wang, D.; Peng, Y.; Jia, H. Green decoration materials selection under interior environment characteristics: A grey-correlation based hybrid MCDM method. Renew. Sustain. Energy Rev. 2018, 81, 682-692. [CrossRef]

25. Masoumi, Z.; Genderen, J.V. Investigation of sustainable urban development direction using Geographic Information Systems (case study: Zanjan city). Int. Arch. Photogramm. Remote Sens. Spat. Inf. Sci. 2019, 13, 1313-1320. [CrossRef]

26. Ribera, F.; Nesticò, A.; Cucco, P.; Maselli, G. A multicriteria approach to identify the Highest and Best Use for historical buildings. J. Cult. Herit. 2019. [CrossRef]

27. Pons, O.; Franquesa, J.; Amin Hosseini, S.M. Integrated Value Model to Assess the Sustainability of Active Learning Activities and Strategies in Architecture Lectures for Large Groups. Sustainability 2019, 11, 2917. [CrossRef]

28. Yang, Y.; Li, B.; Yao, R. A method of identifying and weighting indicators of energy efficiency assessment in Chinese residential buildings. Energy Policy 2010, 38, 7687-7697. [CrossRef]

29. Kuzman, M.K.; Grošelj, P.; Ayrilmis, N.; Zbašnik-Senegačnik, M. Comparison of passive house construction types using analytic hierarchy process. Energy Build. 2013, 64, 258-263. [CrossRef]

30. Šiožinytė, E.; Antuchevičienè, J. Solving the problems of daylighting and tradition continuity in a reconstructed vernacular building. J. Civ. Eng. Manag. 2013, 19, 873-882. [CrossRef] 
31. Ruzgys, A.; Volvačiovas, R.; Ignatavičius, Č.; Turskis, Z. Integrated evaluation of external wall insulation in residential buildings using SWARA-TODIM MCDM method. J. Civ. Eng. Manag. 2014, 20, 103-110. [CrossRef]

32. Šiožinytė, E.; Antuchevičienè, J.; Kutut, V. Upgrading the old vernacular building to contemporary norms: Multiple criteria approach. J. Civ. Eng. Manag. 2014, 20, 291-298. [CrossRef]

33. Medineckiene, M.; Dziugaite-Tumeniene, R. Energy simulation in buildings with the help of multi-criteria decision making method. In Proceedings of the 9th International Conference on Environmental Engineering (ICEE), Vilnius, Lithuania, 22-23 May 2014.

34. Chen, L.; Pan, W. A BIM-integrated Fuzzy Multi-criteria Decision Making Model for Selecting Low-Carbon Building Measures. Procedia Eng. 2015, 118, 606-613. [CrossRef]

35. Sedláková, A.; Vilčeková, S.; Krídlová Burdová, E. Analysis of material solutions for design of construction detailsof foundation, wall and floor for energy and environmental impacts. Clean Technol. Environ. Policy 2015, 17, 1323-1332. [CrossRef]

36. Motuzienè, V.; Rogoža, A.; Lapinskienè, V.; Vilutienė, T. Construction solutions for energy efficient single-family house based on its life cycle multi-criteria analysis: A case study. J. Clean. Prod. 2016, 112, 532-541. [CrossRef]

37. Vujosevic, M.L.; Popovic, M.J. The comparison of the energy performance of hotel buildings using PROMETHEE decision-making method. Therm. Sci. 2016, 20, 197-208. [CrossRef]

38. Tomczak, K.; Kinash, O. Assessment of the Validity of Investing in Energy-Efficient Single-Family Construction in Poland - Case Study. Arch. Civ. Eng. 2016, 62, 119-138. [CrossRef]

39. Seddiki, M.; Anouche, K.; Bennadji, A.; Boateng, P. A multi-criteria group decision-making method for the thermal renovation of masonry buildings: The case of Algeria. Energy Build. 2016, 129, 471-483. [CrossRef]

40. Zavadskas, E.K.; Antucheviciene, J.; Kalibatas, D.; Kalibatiene, D. Achieving Nearly Zero-Energy Buildings by applying multi-attribute assessment. Energy Build. 2017, 143, 162-172. [CrossRef]

41. Cortes, J.P.R.; Ponz-Tienda, J.L.; Delgado, J.M.; Gutierrez-Bucheli, L. Choosing by advantages; benefits analysis and implementation in a case study, Colombia. In Proceedings of the 26th Annual Conference of the International Group for Lean Construction (IGLC), Chennai, India, 16-22 July 2018.

42. Guzmán-Sánchez, S.; Jato-Espino, D.; Lombillo, I.; Diaz-Sarachaga, J.M. Assessment of the contributions of different flat roof types to achieving sustainable development. Build. Environ. 2018, 141, 182-192. [CrossRef]

43. Moghtadernejad, S.; Chouinard, L.E.; Mirza, M.S. Multi-criteria decision-making methods for preliminary design of sustainable facades. J. Build. Eng. 2018, 19, 181-190. [CrossRef]

44. Zolfani, S.H.; Pourhossein, M.; Yazdani, M.; Zavadskas, E.K. Evaluating construction projects of hotels based on environmental sustainability with MCDM framework. Alex. Eng. J. 2018, 57, 357-365. [CrossRef]

45. Arroyo, P.; Mourgues, C.; Flager, F.; Correa, M.G. A new method for applying choosing by advantages (CBA) multicriteria decision to a large number of design alternatives. Energy Build. 2018, 167, 30-37. [CrossRef]

46. Beltrán, R.D.; Martínez-Gómez, J. Analysis of phase change materials (PCM) for building wallboards based on the effect of environment. J. Build. Eng. 2019, 24, 100726. [CrossRef]

47. Velasquez, M.; Hester, P.T. An Analysis of Multi-Criteria Decision Making Methods. Int. J. Oper. Res. 2013, 10, 56-66.

48. Aruldoss, M.; Lakshmi, T.M.; Venkatesan, V.P. A Survey on Multi Criteria Decision Making Methods and Its Applications. Am. J. Inf. Syst. 2013, 1, 31-43. [CrossRef]

49. Ho, W. Integrated analytic hierarchy process and its applications - A literature review. Eur. J. Oper. Res. 2008, 186, 211-228. [CrossRef]

50. Vaidya, O.S.; Kumar, S. Analytic Hierarchy Process an Overview of Applications. Eur. J. Oper. Res. 2006, 169, 1-29. [CrossRef]

51. Forman, E.H. Facts and fictions about the analytic hierarchy process. Math. Comput. Model. 1993, 17, 19-26. [CrossRef]

52. Antucheviciene, J.; Kala, Z.; Marzouk, M.; Vaidogas, E.R. Solving Civil Engineering Problems by Means of Fuzzy and Stochastic MCDM Methods: Current State and Future Research. Math. Probl. Eng. 2015, 2015, 1-16. [CrossRef]

53. Mandic, K.; Delibasic, B.; Knezevic, S.; Benkovic, S. Analysis of the financial parameters of Serbian banks through the application of the fuzzy AHP and TOPSIS methods. Econ. Model. 2014, 43, 30-37. [CrossRef] 
54. Ayhan, M.B. A fuzzy AHP approach for supplier selection problem: A case study in a Gearmotor company. Int. J. Manag. Value Supply Chain. 2013, 4, 11-23. [CrossRef]

55. Saaty, T.L. Decision making with the analytic hierarchy process. Int. J. Serv. Sci. 2008, 1, 83-98. [CrossRef]

56. Li, L.; Shi, Z.H.; Yin, W.; Zhu, D.; Ng, S.L.; Cai, C.F.; Lei, A.L. A fuzzy analytic hierarchy process (FAHP) approach to eco-environmental vulnerability assessment for the danjiangkou reservoir area, China. Ecol. Model. 2009, 220, 3439-3447. [CrossRef]

57. Łuczak, A.; Wysocki, F. Linear ordering of objects from application of fuzzy AHP and TOPSIS. Stat. Rev. 2011, 1-2, 1-23.

58. Stoltmann, A.; Bućko, P.; Jaskólski, M. Multi-criteria investment decision support model using fuzzy Analytic Hierarchy Process (F-AHP) method for power industry. Sci. Pap. Fac. Electr. Control. Eng. Gdan. Univ. Technol. 2015, 47, 179-182.

59. Online Output Softwares. Available online: http://www.onlineoutput.com/ (accessed on 18 November 2019).

60. Kolendo, Ł.; Ogrodnik, K. The selected criteria of location of solar housing development. In Urban Planning in Spatial Economy; Chmielewski, J.M., Ed.; Warsaw University of Technology: Warsaw, Poland, 2016; pp. 127-141.

61. Kolendo, Ł.; Ogrodnik, K. Multi-criteria analysis of the usability of the area of Bialystok for solar housing development. In Urban Planning in Spatial Economy; Chmielewski, J.M., Ed.; Warsaw University of Technology: Warsaw, Poland, 2016; pp. 142-154.

62. Hejmanowska, B.; Hnat, E. Multi-factoral evaluation of residential area locations: Case study of Podegrodzie local authority. Arch. Photogramm. Cartogr. Remote Sens. 2009, 20, 109-121.

63. Majerska-Pałubicka, B. The quality of built environment in aspects of quality of natural environment based on examples of eco-settlement. Archit. Et Artibus 2010, 2, 57-62.

64. Jaroszewicz, J.; Bielska, A.; Szafranek, A. Application of map algebra to determine the lands preferred for building development. Arch. Photogramm. Cartogr. Remote Sens. 2012, 23, 127-137.

65. Ahmed, F.; Kilic, K. Fuzzy Analytic Hierarchy Process: A performance analysis of various algorithms. Fuzzy Sets Syst. 2019, 362, 110-128. [CrossRef]

66. Özdağoğlu, A.; Özdağoğlu, G. Comparison of AHP and Fuzzy AHP for the multicriteria decision making processes with linguistic evaluations. İstanbul Ticaret Üniversitesi Fen Bilimleri Derg. Yll 2007, 1, 65-85.

67. Kabir, G.; Hasin, M.A.A. Comparative analysis of AHP and Fuzzy AHP models for multicriteria inventory classification. Int. J. Fuzzy Log. Syst. 2011, 1, 1-16.

68. Ishizaka, A. Comparison of Fuzzy logic, AHP, FAHP and Hybrid Fuzzy AHP for new supplier selection and its performance analysis. Int. J. Integr. Supply Manag. 2014, 9, 1-22. [CrossRef]

69. Mosadeghi, R.; Warnken, J.; Tomlinson, R.; Mirfenderesk, H. Comparison of Fuzzy-AHP and AHP in a spatial multi-criteria decision making model for urban land-use planning. Comput. Environ. Urban. Syst. 2015, 49, 54-65. [CrossRef]

70. Prusak, A.; Stefanów, P.; Gardian, M. Graphic Form of Questionnaire in AHP/ANP Research. Mod. Manag. Rev. 2013, 20, 171-189.

71. Matusiak, M.; Palicki, S. Multi-Criteria Analysis: Housing Needs and Preferences of Poznan Residents-Recommendations for Housing Policy; Poznan University of Economics and Business: Poznan, Poland, 2015.

(C) 2019 by the author. Licensee MDPI, Basel, Switzerland. This article is an open access article distributed under the terms and conditions of the Creative Commons Attribution (CC BY) license (http://creativecommons.org/licenses/by/4.0/). 